\title{
The Philosophy of Koranic and Biblical Interpretation
}

\author{
Zaimul Am ${ }^{1}$, Sihabudin Noor ${ }^{2}$ \\ ${ }^{1}$ Department of Islamic Education, University of Muhammadiyah, Tangerang, Indonesia \\ ${ }^{2}$ Department of Islamic Communication and Broadcasting, UIN Syarif Hidayatullah, Jakarta, Indonesia
}

Email address:

zaimul.am@uinjkt.ac.id(Z.Am), Sihabudin.noor@uinjkt.ac.id(S. Noor)

\section{To cite this article:}

Zaimul Am, Sihabudin Noor. The Philosophy of Koranic and Biblical Interpretation. International Journal of Philosophy.

Vol. 6, No. 3, 2018, pp. 76-83. doi: 10.11648/j.ijp.20180603.13

Received: September 15, 2018; Accepted: September 29, 2018; Published: November 1, 2018

\begin{abstract}
This article attempts to explain the concept of using the method of hermeneutics in interpreting the Koran and the Bible and polemic among the philosophers associated with it. This research is a content analysis as long as it relates to the study of the thoughts of philosophers about Koranic and Biblical Interpretation both from primary sources and secondary sources. Researcher also uses descriptive-analytical methods because this research is an analytical and critical exposure to various philosophers' thoughts in understanding the scriptures. The results of this study show that there are quite a number of differences among Muslim thinkers in interpreting the Koran and among Christian scholars in interpreting the Bible. The use of hermeneutics in Koranic interpretation has caused polemic in Muslim scholars whether it is permissible or prohibited in understanding the sacred text as is the case among Christian scholars in Biblical interpretation.
\end{abstract}

Keywords: Hermeneutics, Koranic Interpretation, Biblical Interpretation

\section{Introduction}

It is important to consider the historical background of Koranic interpretation. In the early days of Islam, the only commentator of the Koran was the Messenger of Allah himself. The Messenger of Allah understood the Koran in general and in detail after Allah gave him the ability to memorize and to explain the meaning of Koranic verses. Whereas the companions of the Prophet used to understand the Koran generally in matters relating to the outer meaning and laws. The elaborative understanding of the Koran which includes its inner meaning and detailed aspects of the meaning it contains is not easy for companions of the Prophet if they only adhere to their knowledge of the language of the Koran alone. Therefore, they always ask the Messenger of Allah when they find difficulties in understanding the Koran. [2].

Ulama (Muslim scholars) differed regarding the relative truth of understanding of of Prophet's companions. Ibn Khaldun was a Muslim thinker who believed that companions of the Prophet had perfect knowledge of the Koran because they learned directly from, and experienced the events of revelations of Koranic verses with, the Prophet. According to Ibn Khaldun, the Koran was revealed in Arabic and surely the companions of the Prophet understood very well the meaning of words in the Koran in the form of vocabulary and its composition in sentences. But Ibn Khaldun's opinion is refuted by argument that although the Koran was revealed in Arabic, it did not necessarily mean that all companions of the Prophet understand the words in Koranic verses or, at least, there must be at different levels in their ability to understand the Koran. [2]

In the tradition of explaining the meaning of Koranic verses, we will see two kinds of issues. First, explanation of the meaning of Koranic verses through the use of words which are synonymous or having close meaning to the word in Koranic verses (referred to as the method of tafsir). Second, explanation of the meaning of Koranic verses through the use of a word which has far different meaning from the words contained in the Koran but is seen as still having relevance or context (referred to as the method of ta'wîl or metaphoric interpretation).

In etymological meaning, Tafsìr means to explain (al$\hat{\imath} d$ hahh or al-tabyin). Tafsîr comes from the root of word alfasru which means clear and open (al-kasyf) and it can be interpreted as revealing what is closed (kasyf al-mughaththâ). Thus, tafsir is defined as expressing the meaning of difficult words. The word tafsir in this sense can be referred to Surah 
al-Furqān[25]:33. In this verse, the word ahsanu tafsîran contains the meaning of ahsanu bayânan wa tafshîlan (best explanation and description. But what is very important to say is the etymological understanding of tafsir which includes sensory explanation (al-kasyf al-hissî) and an explanation of the meaning of words (al-kasyf'an al-ma'ânî). [3]

In terms of terminology, Muslim scholars define tafsir as the knowledge used to understand the Book of Allah revealed to Prophet Muhammad, explaining the meaning and revealing the law and its wisdom. There are quite a number of definitions given by ulama to the science of interpretation. But those various definitions are in the range of view that interpretation is the science that addresses the purpose of God's word as far as human beings can understand. This definition includes all that relates to understanding the meaning and explanation of the meaning of words contained in Koranic verses.

Related to tafsîr, but then in its development becomes different from $t a f s \hat{\imath} r$ is $t a$ 'wîl. Ta'wîl comes from the root of word al-awl which means to return (al-rujî̀). While the phrase awwal al-kalâm aw ta'awwalahu (he metaphorically interprets sentences) means dabbarahu (studying it), qaddarahu (measuring it) and fassarahu (explaining it). Whereas in terms of terminology, the word $t a^{\prime}$ wîl has at least two different definitions. First, if Salaf scholars use the word $t a^{\prime}$ wîl, what is meant is to interpret the sentence or explain its meaning regardless of whether the meaning is the same as or different from the explicit word. In this context, the word tafsir and ta'wîl are synonymous. Salaf scholars explained that the word ta'wil was the essence of the sentence. If the sentence contains an order, then of course the meaning is the essence of the action that was ordered. Second, Khalaf scholars defined ta'wîl as turning the explicit meaning (alrâjih) to the implicit meaning (al-marjûh) because of the argument that relates it. Therefore, ta'wîl becomes broader than tafsîr and it was said that tafsīr related to transmission (al-riwâyah) while ta'wîl is related to creative thinking (aldirâyah). Abu Nashr al-Qusyayri stated that tafsīr is seen as following (al-ittib $\left.\hat{a}^{\prime}\right)$ and listening (al-simâ $\left.{ }^{\top}\right)$ while ta'wîl is seen as deduction (al-istinbâth). [4]

In the Western world, science that studies interpretation is hermeneutics. This field of science emerged in the 15 th century $\mathrm{AD}$ as a historical methodology and criticism for analyzing the text. The term hermeneutics finds its roots in Greek verb hermeneuein, which means interpreting and in Greek noun hermeneia which means interpretation. Hermeneutics is an intellectual and philosophical discipline that examines the nature and interpretation's theory of human expression. Oxford English Dictionary refers to hermeneutics as a branch of science that examines the theory of interpretation, especially the interpretation of scripture. [5]

Hermeneutics is also seen as a study of the principles and methods by which a text in the past has been interpreted to find meaning relevant to the current context. Palmer states that hermeneutics is not only a science of interpretation but also a knowledge of understanding. For Palmer, this discipline incorporates two theories of understanding, namely the problems involved in understanding events in a text, and the question of what understanding itself is in the most fundamental and existential sense. [6]

\section{Hermeneutic Method in Koranic Interpretation}

In Islamic thought, there are two things facing each other, namely tafsîr and ta'wîl. Therefore, there are two genres of interpretive approaches, namely tafsîr bi al-ma'tsûr and tafsîr bi al-ra'y. Tafsîr bi al-ma'tsûr is understood as an interpretation that covers what is explained by the Koran and what is narrated from the Prophet and his companions. There are differences of opinion between the ulama regarding whether or not to use ijtihad in interpreting Koranic verses. Some scholars see that the interpretation of the Koran with personal opinions (al-ra'y or ijtihâd) is not permitted. This group of ulama included the interpretation $b i a l-r a^{\prime} y$ into the category of arguing about God without basic knowledge and this was forbidden. They also quoted the hadith from Jundub that the Prophet said, Whoever uses his personal opinion about the Koran is a guilty person even though his opinion is true. Whereas the ulama group eho allows the use of personal opinions (tafsîr bi al-ra'y or ijtihâd) states that the Koran contains many verses that instruct reflection on the meaning of Koranic verses and even denounce those who do not want to contemplate it. They also stated that if the use of tafsirbi $a l-r a^{\prime} y$ is forbidden, of course ijtihad must be prohibited as well. In addition, they refer to the fact that the companions of the Prophet (peace and blessings of Allah be upon him) both read the Koran but they differed in opinion regarding its interpretation. If tafsitr $b i a l-r a^{\prime} y$ is prohibited, surely the companions will not use it.

Whereas those relating to what is narrated from tabi'in, there are differences of opinion among the ulama. Some ulama view the transmission of tabi'in as part of tafsìr bi al$m a ' t s \hat{u} r$ while others include it in the category of tafsìr bi al$r a^{\prime} y$. Tafsîr bi al-ra'y is defined as the interpretation of the Koran by using creative thinking (al-ijtihâd) and is guided by the tools or rules required by the commentator. [7]

Al-Kindi, al-Farabi, Ibn Sina and Ibn Rusyd are Muslim philosophers who often use tafsîrbi al-ra'y and the method of ta'wîl. This is closely related to their efforts to integrate Greek philosophy with Islamic teachings. Al-Kindi was the first Muslim philosopher to use metaphoric interpretation $\left(t a^{\prime} w \hat{l} l\right)$ in his efforts to harmonize religion and philosophy. Al-Kindi interprets QS al-Rahman [55]: 6: And the plants and trees both submit to Him, by mentioning the various meanings of the word sujûd (sajdah), namely 1) prostration in prayer, 2) obedient, 3) change from imperfect to perfection, and 4) obey orders from someone. The fourth meaning applies to the prostration of the stars. Heavenly bodies moved and became a cause for life in a mortal realm. He called the celestial movement as a prostration in the sense that the agents were submissive or obedient to God. [8] 
In the context of Koranic interpretation, Al-Farabi stated that some religious teachings are traditional (al-sam'iyyât) namely things that cannot be proved by reason. For al-Farabi, Koranic verses which mention al-Lawh, al-Qalam and so on should not be understood literally because the word al-Qalam is not a tool for writing and al-Lawh is not a page where various sayings are recorded. Both are symbols for accuracy and preservation. The Koran is also full of descriptions about the Day of Judgment, the Day of Reckoning, Heaven and Hell. Although al-Farabi fully acknowledged the existence of heaven and hell, he reduced it to spiritual matters that had nothing to do with the body. According to al-Farabi, it is the spirit - and not the body - that feels pleasure or pain. [9]

Like al-Farabi, Ibn Sina also uses hermeneutic methods in understanding Koranic verses about the Day of Judgment. One of the terms mentioned in the Koran for the Day of Judgment is al-ma' $\hat{a} d$. According to Ibn Sina, the word al$m a$ ' $\hat{a} d$ means the return of spirit to its nature which is its source and which has been left behind as long as it integrated with the body for a while. [10]

For Ibn Sina, what is meant by the resurrection on the Day of Judgment is only the resurrection of the soul and not physical awakening. If Koranic verses give impression of physical resurrection, this must be understood in two kinds of contexts. First, religion is conveyed to lay people in a language that is easier to understand by those who are not familiar with figurative terms or analogies. The Koran itself, according to Ibn Sina, does not give a sign about this important matter and does not explain in detail the possibility of the awakening of souls and bodies. But in part, it uses metaphors that are physical and some others are very general and having no limits or explanations. Second, humans are not humans in the material or physical sense, but in terms of form (shûrah, form, rûh) that are in the material. Human actions arise because of the form in the material. If it is stated that the form cannot be separated from matter, then the form is destroyed and the material will return to the land or other elements, the human essence is destroyed. If later created in this material a new human form, so what will appear of course is another human being, not a human before. [11]

According to Ibn Sina, religion often makes physical or sensory metaphors in the event of resurrection on the Day of Judgment to be more easily understood by the laity. The scholars, in order to provide motivation and warning to the people, are forced to declare that happiness as well as the misery in the afterlife can be felt physically. [11]

Ibn Rushd stated that the use of physical metaphors regarding the resurrection on the Day of Judgment (al-ma 'âd) is easier to understand than spiritual metaphors (rûhâniyyah). Ibn Rushd later quoted the word of God in the Hadith Qudsi, I have provided for my righteous servants what the eye has never seen, or ears has never heard, or crossing over the hearts of men, and the opinion of Ibn Abbas that in the hereafter nothing comes from the world except only the names. [12]

The above interpretation, which implies the rejection of the possibility of physical awakening, is refuted by other scholars including al-Ghazali. Al-Ghazali views the denial of physical awakening, physical enjoyment in the Heaven, and physical suffering in the Hell as contrary to what the Koran describes about both and at the same time is contrary to the principles of Islamic teachings. [13]

Al-Ghazali also rejected the argument of Muslim philosophers who stated that what was conveyed by the Koran was a metaphor to be more easily understood by the laity. As the examples are anthropomorphic verses (tasybîh) and the Glorious God from what is understood by the laity. Al-Ghazali put forward two arguments to reject the opinion of Muslim philosophers. First, the words contained in anthropomorphic verses (al-tasybîh) must be understood by using the metaphoric interpretation ( $\left.t a^{\prime} w \hat{\imath} l\right)$ based on the Arab tradition in terms of the use of figurative words (al-isti ' $\hat{a r a h}$ ). While the properties of the Heaven and the Hell with various descriptions are very clear and do not require metaphoric interpretation $\left(t a^{\prime} w \hat{\imath} l\right)$. Second, rational arguments prove the impossibility of place, direction, form, hand, eye, and displacement of places for Allah. Thus, anthropomorphic verses like this must be interpreted by using rational arguments. Whereas what God promises in the hereafter is not an impossible matter for God's power. Therefore, Koranic verses regarding this matter can be understood literally. [13]

Ibn Taymiyya refutes the views of Muslim philosophers regarding the possibility of the only spiritual resurrection on the Day of Judgment by using two kinds of arguments, namely textual arguments (al-naqliyyah) and rational arguments (al-'aqliyyah).

First, textual arguments include the conventions of adherents of celestial religions regarding the existence of life after death where a person's deeds during his life in the world are taken into account. Second, the rational argument is the awareness that behind this life there is another life to uphold justice that is not enforced in life in the world. In that other life every human being has retribution for his deeds while they are in the world, if good then good and if bad then bad. [14]

Ibn Taymiyya also quoted Surah al-Rum [30]: 27 and stated that Allah used the word al-nasy'ah al-îla (first creation) to indicate the existence of physical resurrection on the Day of Judgment. Ibn Taymiyya intends to say that why Muslim philosophers deny physical resurrection on the Day of Judgment? Whereas Allah has said that humans will be resurrected on the Day of Judgment for the calculation of deeds. This is certainly not difficult for God who has created man from nothingness (min al-'adam) and raising him in a second life is easier than creating it for the first time from nothing. [14]

From the description above, two problems arise. First, the use of hermeneutic methods in interpreting the verses of the Koran has created two versions of conflicting understanding in which the one version declares the resurrection on the Day of Judgment is only the resurrection of the soul while the other rejects it by stating that the resurrection on the Day of Judgment will include the physical and spiritual resurrection. 
Second, the factors which cause this difference can be traced to the polemic of the use of hermeneutical methods in understanding Koranic verses. Differences of opinion in this section also create two versions of understanding, namely that there are those who allow the use of hermeneutic methods and some reject them. Elaboration of these two versions can help to find out which version is closer to the truth.

\section{Polemics of the Hermeneutic Method in Koranic Interpretation}

In the study of Koranic interpretation, there is controversy regarding the use of hermeneutic method ( $\left.t a^{\prime} w \hat{\imath} l\right)$ in understanding the meaning of words in certain Koranic verses. This controversy is reflected in two things. First, in defining the hermeneutic method ( $\left.t a^{\prime} w \hat{\imath} l\right)$ itself. Second, the implications of defining the hermeneutic method ( $\left.t a^{\prime} w \hat{\imath} l\right)$ in the form of its application in interpreting the words in Koranic verses and their intentions.

As described above, the Salaf scholars understood $t a^{\prime} w \hat{l} l$ as synonymous with tafsir. Ibn Jarir al-Thabari understands $t a$ 'wîl in the sense of interpreting words or explaining them. Because of that, in his interpretation, al-Tabari often expressed opinions about $t a^{\prime}$ wîl the word of God like this (alqawl fi ta'wîl qawlihi Ta'âlâ) or the experts of ta'wîl disagree about this verse (ikhtalaf ahl al-ta'wîl fihâdzih al-âyah). What is meant by al-Tabari is tafsir. [15]

In the view of Salaf, $t a^{\prime}$ wîl only covers three kinds of scope. First, ta'wîl of sentences ( $t a^{\prime}$ wîl al-kalâm) which means returning the word to the speaker's intention or returning the meaning of the word to its essence namely the meaning or purpose of the word. In this sense, ta'wîl was divided into two categories, $t a^{\prime}$ wîl al-insy $\hat{a}^{\prime}$ and $t a^{\prime}$ wîl ikhbâr. Second, one part of ta'wîl insya $\hat{a}^{\prime}$ is $t a^{\prime} w \hat{\imath} l$ al-amr (ta'wîl of command) which means the deeds ordered themselves. Third, ta'wîl ikhbâr (ta'wil of news) is the essence of the news conveyed. The use of Salaf scholars on this $t a^{\prime}$ wîl does not go far from the meaning of the explicit word. In other words, the word $t a^{\prime} w \hat{\imath} l$ is still seen as synonymous with the word tafsir.

Muslim philosophers and Khalaf scholars generally developed the terminology of $t a^{\prime}$ wîl which was different from that of Salaf scholars. Ta'wîl is defined as turning the word from the meaning that is explicit to the meaning implied because there is a proposition that relates it. [15]

The controversy between Salaf and Khalaf including Muslim philosophers about the use of $t a$ 'wîl method in interpreting Koranic verses is reflected in the following exposure. First, that tafsīr refers to transmission (riwâyah) while ta'wîl refers to thought (dirâyah). Second, tafsir is disclosure and explanation. The disclosure and explanation of God's purpose must refer to the valid narrations of the Prophet or from the companions of the Prophet who witnessed Koranic revelation. They are people who know various events related to the revelation of the Koran, interact with the Prophet in their daily life and always ask the Prophet about various difficulties in understanding the meaning of Koranic verses. [3]

Al-Ghazali rejected the definition of ta'wîl as changing the word from explicit meaning to implicit meaning because of the proposition (dalâlah) which obliges it. According to alGhazali, the correct ta'wîl is ta'wîl which corresponds to what is shown by Koranic text (nushûsh) and Sunnah of the Messenger of Allah. According to al-Ghazali, what is conveyed by the Koran is true because the vanity will not be conveyed by the Koran. People who do ta'wîl (ashâb alta'wîl) have fallen into two kinds of prohibitions. First, we must not establish anything from the meaning of Koranic verses and the Sunnah of the Messenger of Allah except if we have discussed it at length to allow it to be based on reason. According to them, reason shows the truth of their opinion and they do ta'wîl even by violating what is forbidden. Second, the heart cannot decide what it believes from what is conveyed by the Messenger of Allah. if you don't believe that the outer meaning is meant. Many ta'wîl are chaotic (al-ta'wîlât mudhtharabah). The result is to alienate the Koran and Sunnah as a proposition or clue as to what Allah has told His servants. The main mission of the Prophet is to deliver the news and the Koran is great news. [16]

Al-Ghazali also stated that the perpetrators of $t a^{\prime} w \hat{\imath} l$ mentioned Koranic verses and the Sunnah of the Messenger of Allah only for the sake of belief (al-I'tiqâd) and not for the sake of guideline (al-i 'timad). If the text coincides with their rational arguments, they make it as a proposition. But if it is different or contradictory, they do $t a^{\prime} w \hat{\imath} l$ on it. According to al-Ghazali, in this way, the word $t a^{\prime}$ wîl has been used outside its original meaning. Because true $t a^{\prime} w \hat{l} l$ in the Koran and Sunnah of the Messenger of Allah is truth or essence (alhaqiqah) which is the source of reference for the study and not to turn the meaning of the explicit words as understood by people who deviate from the religious text (al-nushûsh). [16]

\section{Hermeneutic Method in Biblical Interpretation}

Modern Hermeneutics stems from an effort to formulate the principle of interpretation with the growing awareness that the holy book is actually a historical document in which textual truths and their meanings are closely related to the time and space when the scriptures were revealed. At first the term hermeneutics was placed in a holy sphere. [17]

God's message can only be understood through its own expression, which is received with explicit uncertainty about its truth and guilt. The insistence of this message is irrationality, a kind of unconsciousness that befell the recipient. Only people who have a rational interpretation method - that is, first generation hermeneutic interpretersmay be the source of truth or a misstatement. [17]

Hermeneutics comes from the verb hermeneuein and the noun hermeneia which refers to the message of Lord Hermes and which is the source of the origin of the word. Hermes is 
associated with the function of transmitting what is beyond the reach of human understanding into a form that can be understood by human reason. This process of understanding the message brought in by Hermes is implicitly summarized in the three basic directions of the meaning of the verb hermeneuein and the hermeneutical nouns in use in ancient times. These three directions, as reflected in the verb hermeneuein form, are to say, to explain and to translate. These three meanings can be expressed through verbs interpreting even though each of them has the meaning of independent and significant interpretation. In this context, interpretation can refer to three types of issues: oral reading, explanation and translation.

In the West, there are six patterns of using hermeneutic interpretation. First, biblical interpretation. Second, philological methodology. Third, the knowledge of linguistic understanding. Fourth, the methodological basis for human sciences. Fifth, phenomenology of being. Sixth, the system of interpreting symbols. [6]

First, Biblical interpretation which - in the early of its phase-distinguishes interpretation (commentary or exegesis) from the rules, methods or theories those make it up (hermeneutics). However, the general use of the concept of biblical interpretation in English refers to Biblical hermeneutics of explaining or interpreting. The results of Gerhard Ebeling's study of Luther's hermeneutics show that methods as well as explanations, theories and interpretations of the Bible are included in what can be called as Luther's hermeneutics. This then extends the concept of hermeneutics to include all theories of interpretation, both implicit and explicit, as well as those that refer back to various interpretive practices of the Old Testament.

Second, philology which developed in the 18th century together with the emergence of the school of rationalism in philosophy. A historical-critical approach to biblical studies along with various traditional and grammatical historical schools in Biblical interpretation confirms that various interpretative methods in biblical studies can also be applied to other texts. [6]

Third, that which closely related to various forms of hermeneutics - and which can be attributed to it-is hermeneutics initiated by Schleiermacher. His conception of interpretation seeks to overcome rules and procedures in order to create a coherent hermeneutics that explains various conditions for understanding dialogue. This general conception of hermeneutics is noted by Palmer as marking the beginning of non-disciplinary hermeneutics which is very important for the study of related fields. For the first time, hermeneutics becomes a study of understanding itself. [6]

Fourth, there are efforts to expand hermeneutics as a basis for all human sciences, whether as literary studies, law or various other types of activities. Interpreting all human activities requires a historical understanding that is different from quantitative natural sciences. Interpretation requires involvement in the object of study through personal knowledge of what actually a human is. What is needed by the human sciences is a critique of historical reason which is roughly equivalent to Kant's criticism of pure reason for the natural sciences. Dilthey's efforts to find a humanistic basis suitable for Geisteswissenschaften have created interpretations, namely to interpret objects that are always historical. [6]

Fifth, phenomenological study as a Dermin's hermeneutics initiated by Martin Heidegger. This work marks a major transition not only in hermeneutic practice but also in the object of analysis. Heidegger turned his attention to the description of Being itself. When he turned to his phenomenological analysis, the basic model of Dasein became understanding and interpretation. The implication is that hermeneutics develops to include ontology and epistemology at the level of human obligation to understand an object.

Sixth, the final part of the short list of modern definitions of harmeneutics in particular can be found in the Paul Ricouer interpretation system which is concerned with symbols. He chose a definition of textual interpretation as central hermeneutics. According to Ricouer, through hermeneutics, people will always understand the theory of rules that exist in an interpretation - that is, the interpretation of a specific text, or a collection of signs that can be considered as a text. [19]

These signs can be divided into two categories. First, signs those have one meaning (univocal). Second, signs those have many meanings (equivocal). The second type is the focus of hermeneutics. Equivocal signs may contain a linguistic unity with the meaning of visible part of the text which will also create a series of other meanings or deeper meanings. Ricouer proposed two very different forms of hermeneutics. One of them was stated by Rudolf Bultman who wanted to demythologize Biblical text by finding the meaning behind the symbol. Another way is to destroy the symbol through caution and hesitation in order to create a new system to interpret the world as it is. With these two conflicting symbol interpretation approaches, Ricouer states that there is no universal theory of interpretation because there are only different interpretations and contradictions. [19]

Controversy in Biblical interpretation, as Ricouer pointed out, can be divided into two major categories. First, relating to the relationship between the importance of understanding the character of Biblical writers with biblical interpretation. Second, the relationship between Biblical interpretation and the development of science and modernity.

In the first category, controversy occurred between Schleiermacher and Gadamer. Schleiermacher is a figure who is seen as the father of modern hermeneutics. Schleiermacher has transformed traditional Biblical interpretation into a general hermeneutic that covers all types of texts. In this case, what is meant by text refers to everything, not only words written but also conversation, understanding and so on.

By raising the study of hermeneutics to a universal level, Schleiermacher has incorporated hermeneutics into a new world of understanding and interpretation. What emerges later is a methodology for humanitarian sciences. [20] 
Schleiermacher distinguishes between reading a text and dialogue in conversation. The reader must play two roles at once in the dialogue: the role of the writer and the role of the recipient of the text. He called this as a significant conversation and he then emphasized the importance of understanding a series of thoughts in the text as if it were a life moment that was being lived. The discussion then turned to a new method of understanding the meaning of the text, and in this case Schleiermacher emphasized two aspects of interpretation: grammatical interpretation and psychological interpretation.

Grammatical interpretation methods include understanding text that requires an understanding of common words and languages. One must examine the words in relation to the sentence, and the context of the sentence in the paragraph, and so on until the understanding of the text can be achieved accurately. This then led to what Schleiermacher called as a hermeneutic circle. According to Schleiermacher, the method of grammatical interpretation is that the vocabulary and historical life of biblical writers together form a whole from which various writings must be understood as a part. Schleiermacher shows how studies of linguistic history, along with culture and people, become absolute for the method of grammatical interpretation. Language is limited by the life of people and by the same interests in a society which will create a new genre that reflects the history of biblical writers. [22]

The method of psychological interpretation has caused more controversy and criticism of Schleiermacher. This method of psychological interpretation includes steps into the creative thinking of biblical writer, which is also known as the concept of author's intent. [23]

According to Schleiermacher, answers to hermeneutical issues are understanding the individual goals of the author in writing the text and meaning intended by him. This method relies heavily on intuitive techniques (divinatory technique) which can explain why certain words or sentences are used in the text. By using this concept of intuition, according to Schleiermacher, people can re-create personalities and situations that are closely related to biblical writers. By encouraging the interpreter to transform himself into biblical writer, this method of intuition will attempt to gain direct understanding of Biblical writer as an individual. According to Schleiermacher, a commentator must be familiar with the life and times of Biblical writers. Familiarity with the biographical and historical context of Biblical writers is a condition for psychological interpretation methods. [22]

According to Gadamer, the problem of psychological interpretation lies in the necessity of understanding Biblical writers in interpretation. For Gadamer, considering Biblical writers and what they meant in interpreting the text was important in hermeneutics. But what is far more important is understanding the specific conditions in which the text was written and to whom the text was intended. Gadamer states that the focus of the study is not biblical writers and how the writers express their ideas. But it is the interpreter and how he understands the idea in the movement of understanding and interpretation. [20]

Richard Corliss criticized Schleiermacher's hermeneutics with an example of someone who came to a different church service from the church he usually visited. He has often attended church services and is well aware of the parts of the service. In the previous church, he knew the pastor who delivered the sermon. Whereas in this newly visited church he did not know the priest. According to Corliss, that person would still be able to understand the contents of the sermon even though he did not know the priest. Corliss believes that understanding the contents of the sermon does not require knowledge of the pastor's personal life. Things like this also apply to the Bible. People may not know biblical writers. But he could still understand what was conveyed by understanding the religious traditions those were the background for what was written. [24]

In second category, relationship between Biblical interpretation and development of science and modernity. The fundamental problem in this case is that Bible textually gives a picture that is suggested as contrary to the science or biblical exegetes regard their literal interpretation of Bible as a dogma that has absolute truth.

There is a group in Christianity which is called as the creation scientists who maintain a literal interpretation of the history of the creation of nature as contained in the Book of Genesis and reject the evidence of science. The leaders of this group view the results of scientific research as a threat to their religious beliefs and they believe that there is no meeting point between faith in the Bible and the belief in various scientific theories such as the theory of evolution. In addition, there are mainstream groups of Christians and Jews who believe that there is no conflict between the teachings of the Bible and the theory of evolution. Among these two groups there are other groups, namely fundamentalists who hold to literal interpretations and receive scientific data about the age of the earth. [25]

The different perspectives on the relationship between biblical interpretation and the development of science can be traced to differences in looking at the Bible itself. In the early days, the Bible was seen as the word of God in a narrow sense, as if God revealed every word in the Bible. If Moses is the author of the Book of Genesis and the parts initially explain various events that are only possible to be seen by God, then it must be concluded that God revealed the Book of Genesis as it is. On the other hand, modern Biblical scholars argue that the Bible was written based on inspiration from God. That the authors collect materials and carry out their work like the general writers. At present, there is strong evidence that the authors of the Book of Genesis collected material from various written and oral sources at the time, such as the Babylonian myth of creation and the Mesopotamian story of the Great Flood. [25]

The Illustrated Bible Dictionary even states that the concept of creation in Genesis 1.1-2, 4a is a history of testimony from a human perspective or an earthly perspective. It is a phenomenological history based on the general experience of how an ancient Jew would look at the world. 
The cycle of day and night is the most important component of God's creation and that is what was created first. Then another basic component, the source of rainwater in the sky, was created the second time. Finally the earth is separated from water to become a place for human habitation. This way of working states that the history of creation is conveyed in simple and pre-scientific observational terms because the ancient Jews did not have the same knowledge as the present knowledge of heaven and earth. [26]

However, Lawrence argues that the history of creation in Genesis 1.1-2.3 is a transmission from God because it is very clear that no human has witnessed all these events. This raises an interesting question about how the author of Genesis 1.1-2.3 obtained this transmission? But Lawrence also stated that this history of creation originated from the earth (earthly-centered) and viewed from the perspective of someone who was on earth. [26]

Another important issue is that in many cases, the authors of Book of Genesis often quote traditional sources. But unfortunately, these writers are used to not telling when quoting or adapting parallel writings as happened in Genesis $1.1-2$, 4a concerning the history of creation. By comparing the text of the Book of Genesis with the Story of Creation in Enuma Elish, it can be seen clearly the similarities and differences in terms of the expression. The discovery of the archaeological slate that records the Babylonian account of creation has clarified that account and its relationship to the Book of Genesis. Enuma Elish is an epic verse containing more than a thousand verses and recorded on seven slate sheets. The writers of the Book of Genesis have borrowed many topics from this older Babylonian Tell, but reject topics those contain a theological perspective that is contrary to Christian teaching. [25]

Stadelman expressed his opinion on cosmology contained in the Old Testament. According to him, the modern concept of an unlimited and open universe is unknown in the Old Testament. On the contrary, heaven and earth are seen as locked in a circle of horizons to prevent cosmic water spills. Ancient Jews saw the universe above a three-tiered structure. The earth is considered a vast plain, some of which is sea and some are continents. The earth is planted by mountains, flowing by rivers, and marked by lake dots. The very nature of circling the earth raises ideas among ancient Jews regarding the shape of the circle. [27]

Regarding the comparison between the interpretation of Koranic and Biblical interpretation, it is necessary to explain some of the views of experts on this matter. There is a hermeneutical circle between scriptural texts and their readers, but this circle is formed by objects which govern religion and the methods which govern understanding. In this case, the exegete is not the teacher himself. Therefore, the obligation to understand is governed by what is the main issue in the text itself. [28]

For Ricouer, on the contrary, there is hermeneutics in the Idea of Revelation. In this case, interpreting means explaining the form in the world that arises in front of the text. Thus, the task of philosophical hermeneutics is sensitive to all types of texts. Regarding the Koran, the text is treated as something that moves continuously and not a fixed thing, which is something that is always a step ahead of the interpreter, always open to enter new fields, and always calls for interpretation to start with new. Bruns said that the most important thing in the Koran is not only behind the text in the originating intention, but also what is in front of the text when the text is understood. The Koranic text is always in a contemporary position with the readers and listeners, which is always oriented to the age and condition of the interpreter. He paved the way for the future. [30]

Ricouer stated that reading the Koran in English means not reading the Koran. People must read the Koran in Arabic. This is certainly very different from the Bible because the Bible has been translated into various languages and this translation is generally a reference in understanding the Bible.

\section{Conclusion}

From the description above, it can be concluded that the use of hermeneutics in understanding the verses of the Koran is almost elitist, especially among certain philosophers and commentators. The space for the use of hermeneutics in the interpretation of the Koran is in the range of express words (al-râjih) and the possibility of meaning that is implied (almarjûh). There are clear limits in using hermeneutics in interpreting the verses of the Koran.

The use of hermeneutics in understanding the Bible tends to be broader and, in some sense, more free. In the context of Biblical relations with science, Biblical experts tend to compare diametrically between the Bible and the development of science and then explain clearly the existence of discord between the two.

One of the main factors in this regard is that biblical writers often quote or adapt ancient stories from other civilizations.

\section{References}

[1] QS Al-Qiyamah (75):17-19, QS al-Furqan (25): 33, QS alRum (30): 27.

[2] Al-Dzahabi, Muhammad Husayn, Al-Tafsîrwa al-Mufassirûn, Jeddah: WazarahSyu'un al-Islamiyyahwa al-Da'wahwa alIrsyad, 2010, 33

[3] Al-Dzahabi, Muhammad Husayn 'Ilm al-Tafsîr, Kairo: Dar alMa'arif, $n, d, 5-8$

[4] Al-Suyuthi, Jalal al-Din, Al-Itqân fî̀ 'Ûlûm al-Qur'ân, Kairo: Mushthafa al-Bab al-Halabi, 1935, 173-174

[5] Shorter Oxford English Dictionary on Historical Principles, Vol. I, New York, 2002, 1231

[6] Palmer, Richard E., Hermeneutics: Interpretation Theory in Schleiermacher, Dilthey, Heidegger, and Gadamer, North Western University Press, Evanston, 1969, 4-44

[7] Aththar, Nur al-Din, 'Ulûm al-Qur'ân al-Karîm, Damaskus: Mathba'ah al-Shubul, 1993, 74-86. 
[8] Sharif, M. M., History of Muslim Philosophy, Wiesbaden: Otto Harrassowitz, 1963, 427

[9] Al-Farabi, Arâ' Ahl al-Madînah al-Fâdhilah, Beirut: Dar alMasyriq, 1986, 67

[10] Mursyan, Salim, Al-Jânib al-Ilâhî 'indaIbnSînâ, Beirut: Dar Qutaybah, 1992, 316

[11] IbnSina, Risâlah al-Adhhawiyyahfîamr al-ma‘âd, Teheran: Syams al-Din Tabrizi, 1382, 44, 97

[12] IbnRusyd, Tahâfut al-Tahâfut, Kairo: Dar al-Ma'arif, 1963, 870

[13] Al-Ghazali, Tahâfut al-Falâsifah, tahkikSulaymanDunya, Beirut: Dar al-Ma'arif, 1972, 287, 292-293

[14] Harbi, Muhammad, IbnTaymiyyahwaMawqifuhu min Ahamm al-Firaqwa al-Diyânâtfî 'Ashrih, Beirut: 'Alam al-Kutub, 1987, 314-315

[15] Al-Qaththan, Mannâ', Mabâhitsfî̀ 'Ulûm al-Qur'ân, Kairo: MaktabahWahbah, n. d, 317-318

[16] Al-Ghazali, Qânûn fi al-Ta'wîl, dita'liqdanditahkikoleh Mahmud Bejou, Kairo: Dar al-Salam, 1993, 7-8

[17] Grondin, Jean, Introduction to Philosophical Hermeneutics, New Haven: Yale University Press, 1994, 21-22

[18] Heidegger, Martin, Being and Time, trans. John Macquarrie and Edward Robinson San Francisco: Harper Collins Pub., 1962,27

[19] Ricoeur, Paul, Freud and Philosophy. An Essay on Interpretation, trans. Denis Savage (New Haven: Yale University Press, 1970, 8

[20] Graham, Terry, "The Dual Aspect of Hermeneutics." Studies in Religion. 22(1), 1993, 105-116
[21] Klemm, David E., Hermeneutical Inquiry: Vol. 1, The Interpretation of Texts, Atlanta: Scholars Press, 1986, 57

[22] Schleiermacher, F. D. E. Hermeneutics: The Handwritten Manuscripts, Trans. James Duke and Jack Forstman. Ed. Heinz Kimmerle. (Missoula: Scholars Press, 1977, 100-113

[23] Stiver, Dan R., The Philosophy of Religious Language, Oxford: Blackwell Publishers Ltd., 1996, 88

[24] Corliss, Richard L., "Schleiermacher's Hermeneutic and its Critics.” Religious Studies. 29, 1993, 363-379

[25] Skehan, James W, , Modern Science and the Book of Genesis, Washington: National Science Teacher Association, 1986, 913

[26] Robert, John R., Biblical Cosmology: The Implication for Bible Translation, Journal of Translation, Volume 9, Number 2, 2013, 6-7

[27] Stadelmann, Luis I. J., The Hebrew conception of the world: A philological and literary study, Rome: Pontifical Biblical Institute, 1970, 43

[28] Ricoeur, Paul, "Preface to Bultmann," Essays on Biblical Interpretation, ed. Lewis S. Mudge, Philadelphia: Fortress Press, 1980, 64

[29] Ricoeur, Paul, "The Hermeneutical Function of Distanciation," From Text to Action, trans. Kathleen Blamey and John B. Thompson, Evanston: Northwestern University Press, 2007, 86

[30] Bruns, Gerald L., Hermeneutics, Ancient and Modern, New Haven: Yale University Press, 1992, 105-111

[31] Ricoeur, Paul, "The "Sacred' Text and the Community," Figuring the Sacred: Religion, Narrative and Imagination, trans. David Pellauer, Minneapolis: Fortress Press, 1995, 68 